\title{
OBJECTS IN THE WORLD AND OBJECTS IN MUSEUMS
}

Eva Silvén-Garnert

A growing number of museums nowadays collect objects directly from the society of today, from people's homes and places of work. These objects carry with them rich contextual information about how they have been used and arranged, for both practical and symbolic purposes. But when they enter the museum collections their primary and secondary identities seem to change place, and Daddy's birthday present turns into a pair of stockings.

What is recognized as relevant knowledge and what is discriminated against are expressions of power structures, predominant ways of thinking and scholarly paradigms. What constitutes «knowledge» and how it is organized is not just a matter of course, but rather a matter of discourse. It is continually reappraised, today often starting from categories such as class, gender and ethnicity, or from perspectives such as reflexivity and representation.

There is today, among scholars, an increased readiness to notice the socially and culturally constructed in that which otherwise is taken for granted. Such views not only promote an open attitude to the museums work in periods of fast change, but are also necessary for the future of museums as scholarly institutions. Using this point of view, in this article, I should like to problematize one single part of the complex set of activities that characterize a museum, namely the collecting of objects and their course from a contemporary context to the museum catalogue.

\section{DEFINING AND \\ ORGANIZING KNOWLEDGE}

New light was shed on my earlier experiences and reflections over these issues when I recently read Museums and the Shaping of Knowledge by Eilean HooperGreenhill (1992). In this book the reader is presented with a very interesting discussion on the birth and growth of museums in Western Europe. Inspired by Michel Foucault, the author shows how these museums have defined and organized knowledge using three major models of thought or world-views: the Renaissance, the Classical, and the Modern episteme (cf. Foucault 1970). Every world-view has its corresponding scholarly order and rationality, each relevant in its own time and also connected with some kind of power. 
124 Problematizing that which in our time is presented as natural and at the same time trying to understand the rationality of another age "would be mind-expanding and would offer new possibilities of classifying the world, and even new ways of living in it» (Hooper-Greenhill 1992:5).

Since what has been regarded as relevant knowledge forms a useful background to my own line of thought, I will give a short presentation. The Renaissence episteme was based on an interpretation of objects and their interior characteristics, focusing on a search for similitude. To know was to understand what things had in common in spite of their exterior differences. The museum that expressed this kind of thinking was the "cabinet of curiosity", which Hooper-Greenhill remarks, is a concept symbolizing another kind of rationality, in which these types of collection were "confused and disordered". Instead, HooperGreenhill suggests the expression "cabinet of the world» as being more appropriate (Hooper-Greenhill 1992:80ff, $130 \mathrm{ff}$ ).

These Renaissance forms of knowledge were thrown over in the early 17 th century by the Classical episteme, which was expressed in the collections of the scientific institutions. The establishment of order, systems and hierarchies replaced the earlier search for resemblance, and the classificatory table emerged as the basic structure of knowledge.

Knowledge was now defined according to distinction instead of similarity, and it was the exterior differences between the objects that became conclusive. Classificatory tables were based on observable facts, that which could be seen and measured. The seeing of things was given priority over the reading of things. Thus, vast areas of semiological information were ignored; both meanings and those things which did not have a material identity were excluded from the classificatory table.

At the end of the 18th century there was another break in the idea of knowledge. With the Modern episteme the concept of time, historical context, and function, entered museum collections. Material things were arranged by chronology, or temporal sequence, rather than according to hidden secret resemblances, or the relationships of visible features. Sixteen paintings by Raphael, for example, were arranged to show the artist's personal and professional growth. Paintings were also displayed by «schools». This way of according meaning to objects was in marked contrast to earlier arrangements, which grouped items by theme, material, and size. The visible surface of things was no longer the determining factor in the creation of order in the museum.

Hooper-Greenhill also points out that with the break-through of the modern consciousness of time museums became identified with the past. It is therefore that contemporary research is still such a problem in museums. "Most museums today, for example, collect almost exclusively from among old things, and have extreme difficulty integrating new things into current practices. The endless debates over 'twentieth-century collecting' or 'contemporary collecting' show the difficulty that some museums have in conceptualising their 'functions' as other than in relation to the past.» (Hooper-Greenhill 1992:22.)

Yet another long-term result of the breakthrough of modern thought was the birth of the public museum, addressing ordi- 
nary people. Or - according to Michel Foucault - "the disciplinary museum», with education as its primary mission and turning a country's inhabitants into a useful resource for the state as its avowed purpose. Consequently, the professional curator emerged as a new kind of expert.

Unfortunately, Hooper-Greenhill does not pay as much attention to the museums of the 20th century as to the earlier ones. This is a general tendency in museological surveys; authors are very interested in the original processes of creating museums and their collections, while the museums of today are left to one side with a few comments on exhibitions and visitors. One gets the impression that the main duty of the museums of today is to take care of the already existing collections and popularize them.

\section{CATCHING UP WITH CONTEMPORANEITY}

I myself, however, am working within a museum sphere where questions concerning collecting and research are still highly current issues. For the past twenty years a large number of Swedish museums have been co-operating in the field of contemporary research, documentation and collecting. These are local, regional and central museums of cultural history, each responsible for a particular geographical environment or subject area, and representing public, cultural policy. Contemporary research is a multi-faceted activity, where theoretical, practical and methodological problems are currently examined in working groups and research projects, during training courses and in publications.

Maybe one can regard the break-through of contemporary research among Swedish museums as a reconsideration of the question of relevant knowledge. Slightly more than twenty years ago the collection of objects at the Nordiska Museet and those of some regional museums were examined. The main temporal focus was found to be on the period 1750-1870, while the 20th century was scarcely represented at all. Thematically agriculture and other basic pre-industrial activities dominated together with urban trades. Lower social groups were under-represented.

In order to adjust the imbalance and try to avoid a similar situation in the future the museums decided to go in for contemporary recording, collecting and research. The social base was to be broadened out, the too predominant historical approach was to be balanced out by contemporary interactive fieldwork, and the passive reception of donated objects was to be supplemented by active collecting.

The plans included the idea that this work should be carried out as a joint effort by all the cultural history museums in our country, in terms of co-operation and co-ordination. Today we have a network, Samdok, which operates well, with around eighty museums collaborating; and at the same time a series of societyoriented research projects have brought noisy and dirty work, ordinary homes, and high technology, to the museum stores and archives. Contemporaneity and its everyday features have nowadays become an indispensable part of the museums' field of responsibility; knowledge of our own time in its different varieties has become an accepted part of the cultural heritage. (Cf. Silvén-Garnert 1994. Another English overview of the current 
EVA SILVÉN-GARNERT

126 work of Samdok will be presented in our newsletter Samdokbulletinen 1995:3.)

\section{OBJECTS: SEEN AS A NUISANCE OR SOMETHING OF SIGNIFICANCE}

At first, this new contemporary research was made up mainly of written material and photographs. The material heritage the characteristic of the museums - was not naturally embraced by these new processes of knowledge, although the questions: How will the museums be able to collect 20th century mass-production? How should the responsibility be distributed? was the starting point of the whole project. In the debate of the 1970 s two different lines of thought crystallized one which was more of a natural science and systematic nature and one more humanistic and qualitative.

Those who supported the first idea recommended compulsory deliveries from manufacturers and importers, with the aim of avoiding future "gaps" in the collections. The acquisition of objects was regarded as some kind of technical procedure, where the point was to preserve different types of objects together with data about their production and marketing. In the era of mass-production, the most important thing was not the possibility of associating the object with a certain individual, but the obtaining of a specimen. Those who supported the second line stressed that collecting policy ought to take people and social groups as its starting point, instead of object categories. Influenced by phenomenological theory it was considered important to record ideas and values associated with the objects from their users.
Neither of these two lines of thought prevailed. There was, apparently, very little interest in broad and systematic collecting. Gradually, new stock-taking gave rise to the ominous picture of "the conservation mountain», which little by little resulted in an extremely restrictive acquisition policy at several museums. Not even the user-oriented model gained any supporters. At this time the renewed anthropological interest in the material world had not yet reached Sweden and no positive models of interpretation and analysis were available; research on objects represented an out-of-date positivist paradigm and could not be used in the new cultural analysis. Even at those museums which were engaged in active contemporary research and building exhibitions focused on ideological and society-oriented problems, objects constituted a distinct frontier. The collections were associated with burdensome duties and represented an eternal Sisyphean labour.

Of course objects and the acquisition of objects were discussed among the contemporary-oriented museums - but on the whole as a problem, never as an opportunity or an asset. There were endless discussions on criteria of selection, on the big, bulky and expensive objects, and on the possible importance of collecting modern technology, as well as on the difficulties of selection when there is no time perspective, etc.

But during the last year I have had the feeling that there is, maybe, a change for the better on the way. At the moment we are seeing a growing number of ways in which objects can be useful in analysis. The greatest difficulty is not in acquisition but in the proper integration of objects in 
the research project. This can be achieved in several ways. One approach is to endow the objects with such a role that the project is impossible to conduct without the material part. Another method is for the researcher to use the things as tools to get in touch with his or her «informants». As Henry Glassie puts it, it may sometimes be easier to talk with people about serious issues if one starts with their material belongings. A third approach is to make the moment of acquisition itself analytically usable - for example, people's appreciation of certain belongings can be exposed when they have to decide if they can give the items away or not.

A current example of an object-oriented research project is The Car as an Object and the Cultural Meaning of Automobility, at the Nordiska Museet. Apart from fieldwork among amateur car mechanics and among families with and without a car, both in the cities and in the countryside, a broad acquisition campaign is being carried out. Another larger project, Town Halls as Symbols, focuses on the buildings of the public sector from a cultural analytical point of view, where architecture, adornment, interior fittings and furnishing are read as a symbolic language. I myself am carrying out research on the practical and symbolic meaning of the tools of modern professional painters. For a single individual or an occupational group their tools represent more than just certain stages in the process of work. Above all they are components in physical and mental attitudes to work and professional identity. When a regional museum investigated the Ovako Steelworks, a protective helmet full of scrawls and some tattered clothes were collected as evidence both of individuality and comradeship as well as the working environment. In the home projects museums document the individual's choice, arrangement and combination of the items of mass-production, a continuous process in every family. The Nordiska Museet has, for example, documented the celebrations of a number of families during a whole year and acquired duplicates of all their birthday presents and Christmas gifts.

These kinds of projects call into question the former content of concepts such as "object knowledge" and "connoisseurship». Here, relevant knowledge is not only the museum's systematic classification based on the physical appearance of the objects but also the intangible meaning ascribed to the objects by their users as well as the relations of which they are part (cf. Silvén-Garnert 1995). Maybe a car should not be defined as a means of transport but rather as an expression of a predominant hobby, a piece of handicraft, or perhaps a cult object. A town hall should be considered not only as a functional building but also as a manifestation of democracy, power or service. A paintbrush is not only a tool but also a professional sign. A protective helmet is not only a piece of safety equipment but also a symbol of personal identity. A pair of stockings ought really to be regarded as a birthday present.

\section{NEW IDEAS - OLD STRUCTURES}

But what happens when these artifacts are put into museum collections, when the user's context encounters the museum's object categories? Are these contextual classifications considered as relevant knowledge in relation to objects? 
128 The structural organization of museums, in the form of working methods, categorizations and search systems, criteria for acquisition, exhibition programmes etc, demonstrates the views held of the processes of knowledge. These structures lead us first of all towards discovery of and interest in those phenomena for which there are corresponding categories, while those not categorized are put aside (cf. Foucault 1974). It is therefore important that the cataloguing systems are constructed in such a way as to allow objects with strong contextual information to remain relevant when they enter the museum.

Earlier on, most museum collections were classified according to subject areas such as Kitchen utensils, Furnishing, Textiles, Handicraft, etc. Today many museums are using Outline of Cultural Materials where you can also find such headlines as Food Quest, Food processing and Food consumption, Family, Kinship, Sickness, Death, Sex, Reproduction and Socialization. The basic view of OCM is functional, and, apart from certain problems, it has the advantage of focusing on people's actions as well as relations between people and between people and their things. If, moreover, every item is provided with several OCM classifications and fed into a digital data base, it is possible not to limit them each to a single meaning, and they can be arranged and rearranged according to the various aspects of meaning which are relevant.

Nevertheless, every object is still normally provided with a main keyword, usually based on its physical appearance instead of on the inner relationships revealed by contemporary fieldwork. To some extent, this may be regarded as a left-over from earlier principles of categorization. ${ }^{2}$ However, its justification is mainly of a practical kind; museum objects are not only entries in a data base, but also threedimensional phenomena which are to be handled and must be identifiable. While a birthday present could be anything, it is much easier to imagine what a pair of stockings look like. So, eventually, the contents of Daddy's parcel become a pair of Stockings in the category Normal garb, under the heading Clothing instead of Birthday present in the category Rest days and holidays, under the heading Recreation. $^{3}$

But we should not let practical considerations overshadow these issues; instead we should discuss them openly among different categories of curators. ${ }^{4}$ On the one hand we must find a way to keep the contextual categories from the fieldwork relevant even when the objects reach the collections - otherwise the fieldworkers will not find it meaningful to integrate material culture into their projects. On the other hand we ought to ask ourselves how the museums' "objective" categorizations may affect our conception of objects and their meanings.

Somewhere in this complex we are still dealing with the same problem as in the debates of the 1970s, i e whether the acquisition of objects should be carried out according to subject categories or to social contexts. ${ }^{5}$ It is a question of two different ways of looking at the world, where knowledge from one sphere is invalid in the other. Consequently museums have problems with their acquisition of objects - artifacts which, from one point of view, are extremely valuable, representative and unique will have difficulties in asserting 
themselves from the other point of view, and vice versa.

\section{WHOSE KNOWLEDGE?}

The creation of knowledge as well as its assimilation are looked upon today as more complex processes than previously. We can observe more multi-faceted approaches to museum research projects, with greater susceptibility for comprehensive views, contexts, and transient and occasional values. What ought to be considered as knowledge has been redefined. Daily duties, contemporary homes, routine work, commuters passing by the Central Station of Stockholm - everything can be studied in order to create knowledge about people's lives and conditions.

During my years as a museum professional from the 1970s onwards there has also been a movement away from a self-evident process of knowledge and learning: the «informant" > the curator > the public. Nowadays museums build interactive exhibitions and information centres, in our research projects we talk about reflexivity and representation, and an interview is considered as a joint product of the researcher and the person who is interviewed. Processes of knowledge are seen as working in two directions rather than one: the "informant" and the public, as well as the researcher, learn from, and are changed by, the encounter.

This is the background of my line of argument. It is not a question of chic postmodernist ideas, nor the desire of fieldworkers to favour their own conception of the world. Choice of systems for cataloguing and classification may be regarded as a question of ethics and repre- sentation: how the people who are the focus of our research, their experiences and their world-view, are made visible in museums. Whose categorizations are going to define the objects? Whose facts are going to be accepted as relevant knowledge? If we consider the knowledgeacquisition processes of museums to be two-way, this also ought to be reflected in the way the collections are defined.

\section{NOTES}

1. It is not self-evident that an earlier "user's context" is what people regard as most relevant when an object has entered the museum sphere. The type of information which the public generally seeks at the Department of Collection at the Nordiska Museet is expert knowledge, connoisseurship, i.e. conventional knowledge about objects, such as identifying and dating, or deciphering hallmarks, as well as advice concerning the renovation of furniture, or on the right type of wall-paper, curtains, etc. However, there appears to be greater interest in symbolic dimensions of objects when people, for example, visit museum exhibitions and displays. Researchers, of course, ask to some extent different kinds of questions. I should like to thank my colleague at the Nordiska Museet, Sigrid Eklund Nyström, for this comment.

Another aspect of this issue, which I cannot enter into here, is the transformation of meaning that occurs when articles of everyday use become museum objects: a continuous problem for 20th century modernist artists, such as Marcel Duchamp with his ready-mades and Guillaume Bijl with his men's outfitter's. Cf. Cornell 1993.

2. Cf. Hooper-Greenhill 1992:164-165: though transitions between different world-views are characterized by ruptures, epistemes are not 
130 motionless figures but something in constant oscillation. They do not exist totally marked off from each other; some aspects may still be active while a new episteme is becoming dominant. "The unity of the epistemological framework was not totally seamless.) From this point of view, the idea of «filling gaps» in the collections could also be regarded as a left-over from the model of thought provided by classification tables.

3. It is my colleague, Karin Lövgren, at the Nordiska Museet, who has been grappling with the birthday present/the stockings.

4. In Sweden, the term curator is used to designate the academic staff, irrespective of whether one is working with objects, exhibitions or research projects.

5. At the moment we, at the Nordiska Museet and other Swedish museums, collect objects according to both lines of thought.

\section{REFERENCES}

Cornell, Peter 1993. Saker. Om tingens synlighet. Hedemora: Gidlunds.

Foucault, Michel 1970. The Order of Things.

London: Tavistock.

Foucault, Michel 1974. The Archaeology of Knowledge. London: Tavistock.

Hooper-Greenhill, Eilean 1992. Museums and the Shaping of Knowledge. London \& New York: Routledge.

Outline of Cultural Materials. 1987. 5th rev ed. George P Murdock et al, ed. New Haven: Human Relations Area Files.

Samdokbulletinen 1995:3 (forthcoming). Special issue in English.

Silvén-Garnert, Eva 1994. Contemporary Field Research in Swedish Cultural History Museums. New Aspects on Material Culture. I Actes du séminaire L'objet contemporain. Québec: Musée de la Civilisation, s 71-87.
Silvén-Garnert, Eva 1995. The Body and Its Material Extensions. Practice and Meaning in the Work of Professional Housepainters. Ethnologia Scandinavica. A Journal for Nordic Ethnology 24.

Eva Silven-Garnert is on the curatorial staff of the Department of Field Research and Acquisitions at the Nordiska Museet in Stockholm, the Swedish National Museum of Cultural History. As such she is responsible for the Samdok Secretariat. The author has also, for several years, been doing research in the field of urban ethnology, at the moment, for her $P h D$.

Adr. Nordiska Museet, Box 278 20, S-11593 Stockholm, Fax + 4686664580 